\title{
Migration and the Language Border ${ }^{1}$
}

\author{
ERIC DE GEER
}

Ph.Doctor

University of Uppsala, Sweden

When people move they take their language with them. What happens, however, when they cross a language border? Naturally, this depends on many causes - for instance on how many of them there are, the level of education they possess, on the functions in which they come, and so on.

The language border as a barrier for migration was dealt with earlier by the author. ${ }^{2}$ Particular interest was focused on the Swedish-Finnish language border in Finland and its implications on internal migration and emigration. ${ }^{3}$

Here I want to give further examples on the subject. However, I will start from the other end and first present some empirical evidence that migration may in its turn affect the language border. Accordingly, the first part of this paper will deal with the effects which the number of migrants can have within a language border region in the long run. The second part deals with the opposite approach. Here a number of studies are tested (most of them are my own, one in cooperation with Holger Wester, and one by Martin Klövekorn) for the effects of the language border on different kinds of migration.

The language border has a barrier function regarding communication and information between people. It is, therefore, not surprising that deficits in information result in lower internal migration or in differences in emigration intensities.

The investigation areas of this study are the parish of Myrskylä ${ }^{4}$, (in Swedish Mörskom), some $80 \mathrm{~km}$ east-north-east of Helsinki (in Swedish Helsingfors), the town of Kokkola (Swedish: Gamlakarleby) in Ostrobothnia (Swedish: Österbotten, Finnish: Pohjanmaa) and a line of communities in the south-western corner of Ostrobothnia: i.e. the small town of Kristinestad (Finnish: Kristiinankaupunki) and the parishes of Lappfjärd (Finnish: Lapväärtti) and Isojoki (Swedish: Storå). All investigation areas are situated at, or near, the language border and have language minorities of different sizes and in different stages of development. The language majorities of Myrskylä and Kokkola changed

1 This paper was originally presented as a lecture, held at the Vth Nordic Conference on Labour Migration Research in Norway (Sole, Oslo) in October 1979.

2 De Geer (1977), Chapters VI, VII and VIII.

3 Ibid., pp. 75-83; De Geer (1960a), maps 2a-c and 4a-b with comments and De Geer (1960b), map 11; De Geer (1975) passim; De Geer/Wester (1975), pp. 68-82, figure 13 and the map appendices $1-2$, figures $16.1-16.6$.

4 The spelling of the place-names is determined by the local language majority during the investigation time $(1866 \rightarrow 1900-1950$. 
Figure 1. Investigation areas.

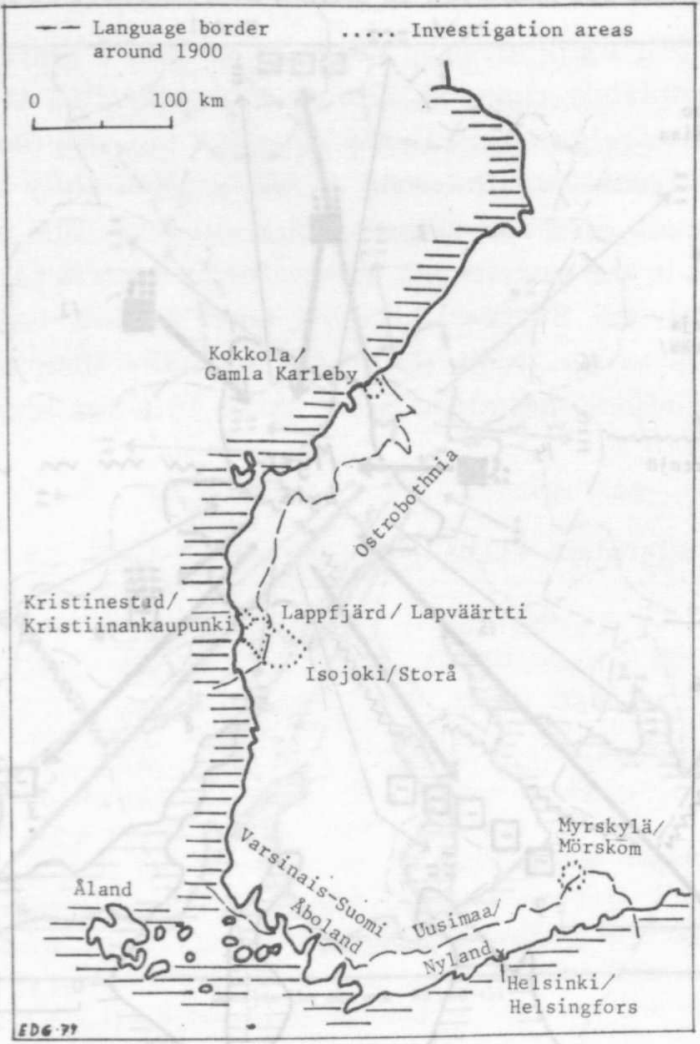

at an early date (about 1900 and 1920 respectively), whereas that of Kristinestad changed recently (about 1970). It is uncertain, when, or even if, the language majority of Lappfjärd will change. In Isojoki the former small Swedish minority has disappeared (Figure 1).

The periods investigated are $1861-90,1901-05,1931,1938,1949-53$ and 1968-72. I will also refer to studies on the periods of $1811-20$ and $1826-30$.

The material used for the study of internal migration consists first of the migration records in the parish registers. These records are also used for the study of the influence fields in Finland of the Finnish Parish, Stockholm. Second, the census of 1950 is used to determine the birthplace fields of some Finnish towns. For emigration I have studied the passport registers and in some cases the official statistics.

\section{The migration influencing the language border}

The influence of migration on the language border in Myrskylä parish

The maps in figures 2 and 3 show the net migration for the periods $1901-05$ 
Figure 2. Myrskylä/Mörskom. Net migration 1901-1905.

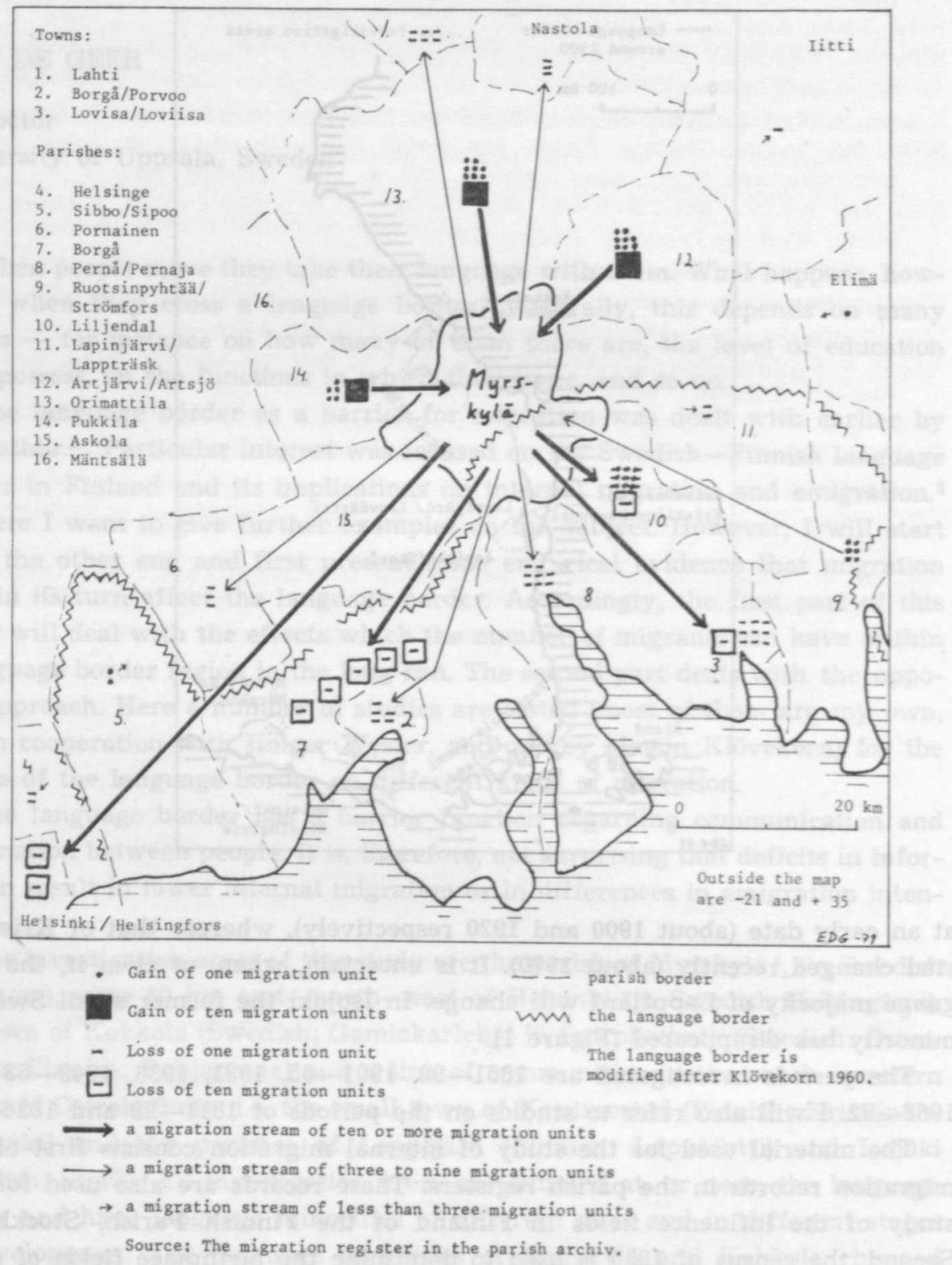

and $1949-53 .^{5}$ For the first of these periods the map gives us a picture of migration by stages. Myrskylä gains strongly from the neighbouring parishes to the north and partly from the east-south-eastern direction, whereas the

5 The total in- and out-migration was 803 and 568 migration units respectively (families or single migrants). 
Figure 3. Myrskylä/Mörskom. Net migration 1949-1953. For an explanation of symbols and names of parishes, see fig. 2.

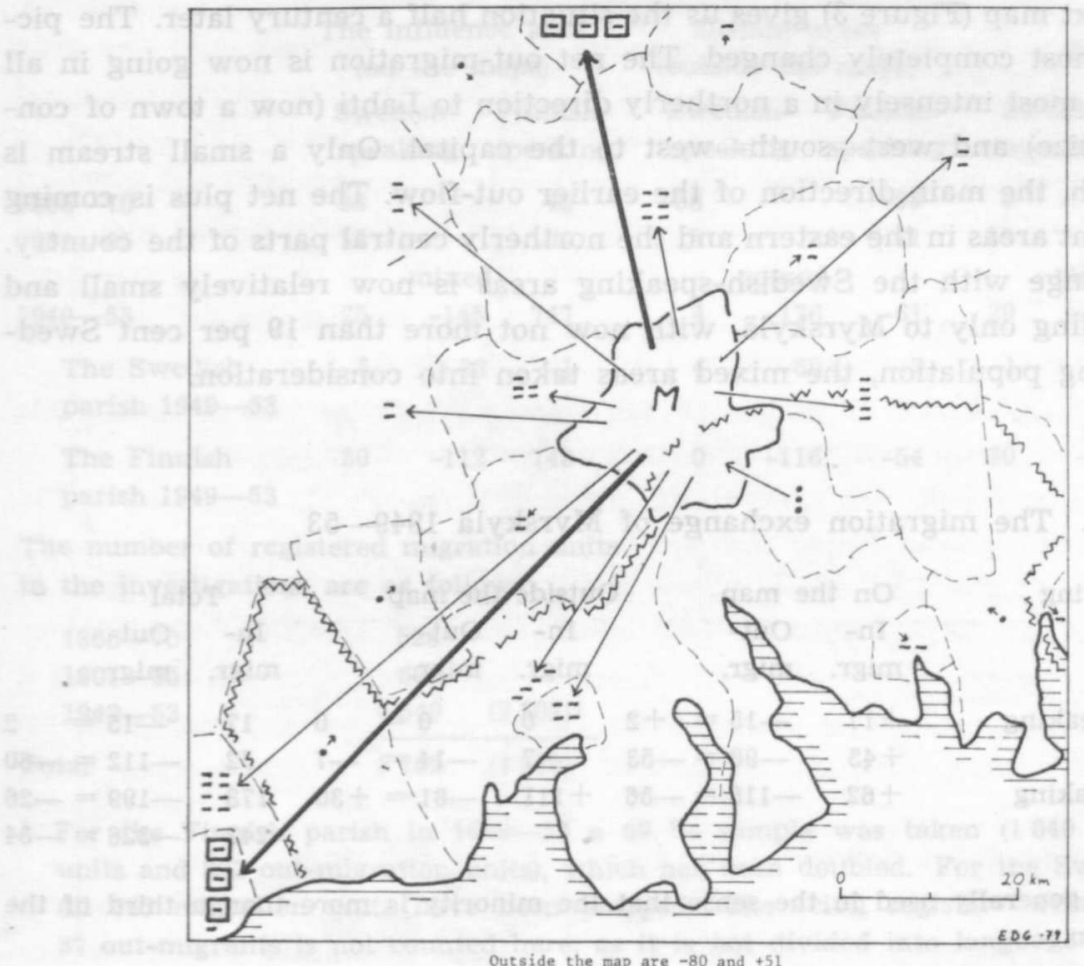

losses go in a southerly direction to the neighbours nearer the coast and to the coastal towns of Borgå (Porvoo), Helsinki and Lovisa (Loviisa). A minor loss to the then small market town of Lahti can be noticed.

How does migration influence the proportions of the language groups? There is no doubt that out-migration is affecting both the Swedish- and the Finnishspeaking populations. Considering the fact that most of the out-migrants are moving to more or less Swedish-dominated areas - Liljendal (12\% Finnishspeaking), Lovisa $(16 \%)$, Borgå town $(25 \%)$, Borgå parish $(22 \%)$, Pernå $(9 \%)$ and Helsinki $(53 \%)$ - it is more than probable that the majority of the migration losses of about 100 migration units were Swedish-speaking. The net-migration gains, numbering about 50, are chiefly coming from the purely Finnishspeaking neighbouring parishes in the northwest to northeast - Pukkila, Orimattila and Artjärvi (Swedish Artsjö). The migration exchanges with the rest of Finland show a deficit of -2 to Swedish-speaking and of -27 to Finnishspeaking areas. ${ }^{6}$ The result is that there is a loss of about 85 Swedish-speaking

6 Lappträsk (Lapinjärvi), Ruotsinpyhtää (Strömfors) and Viipuri (Viborg) have a net loss of -8 to Myrskylä but as they have a mixed language population they are not included. 
migration units, while for the Finnish-speaking population the gains and losses are about equal.

The next map (Figure 3 ) gives us the situation half a century later. The picture is almost completely changed. The net out-migration is now going in all directions, most intensely in a northerly direction to Lahti (now a town of considerable size) and west-south-west to the capital. Only a small stream is going south, the main direction of the earlier out-flow. The net plus is coming from distant areas in the eastern and the northerly central parts of the country. The exchange with the Swedish-speaking areas is now relatively small and corresponding only to Myrskylä, with now not more than 19 per cent Swedish-speaking population, the mixed areas taken into consideration.

Table 1. The migration exchange of Myrskylä 1949-53

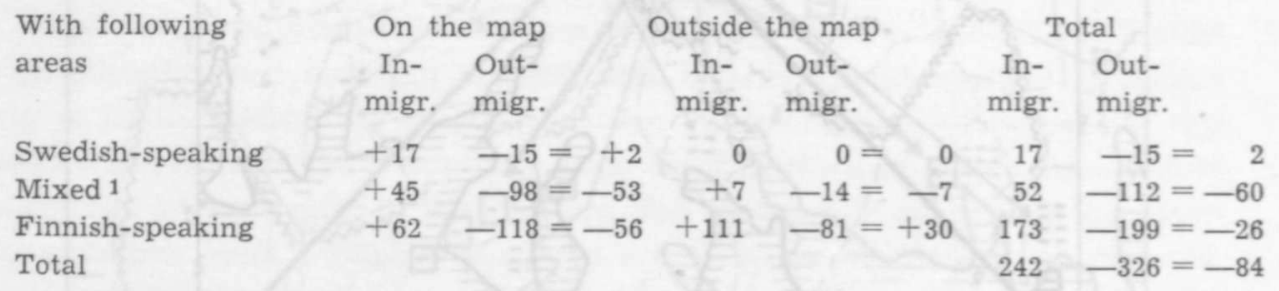

1 Mixed is generally used in the sense that the minority is more than a third of the population.

Of a total of 568 migration units, two-thirds of the exchange was with Finnish-speaking, 29 per cent with mixed and 6 per cent with Swedish-speaking parishes. The net outflows are going to Finnish-speaking and mixed areas, whereas the net inflow is coming from purely Finnish-speaking areas (cf. Table 1). The conclusion is that the proportions between the language groups are still changing in favour of the Finnish-speaking population. This, in turn, is chiefly dependent on the migration factor.

The influence of migration on the language situation in the town of Kokkola/Gamlakarleby in 1866-1953

Kokkola/Gamlakarleby is situated near the northernmost part of the Swedish-speaking area in Ostrobothnia. The development of the language situation has been remarkable: from an almost Swedish-speaking town (84\%) a century ago to a town today with an equally large Finnish-speaking majority $(83 \%)$ (see also figure 17). Migration has been investigated for the periods of $1866-70$, 
$\mathrm{Tab}$ e 2. The net migration results of Kokkola during the periods of $1866-$ $70,1901-05$ and $1949-53$

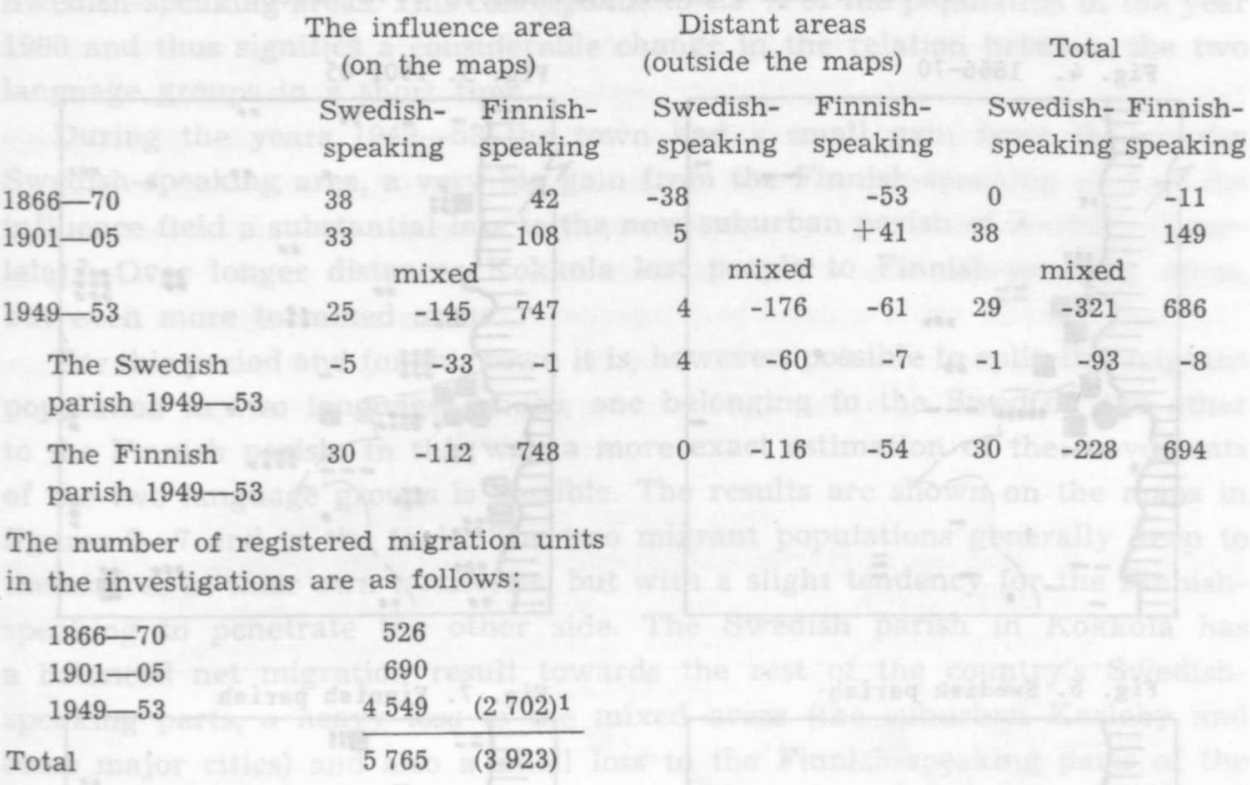

1 For the Finnish parish in $1949-53$ a $50 \%$ sample was taken (1 040 in-migration units and 802 out-migration units), which has been doubled. For the Swedish parish all 865 migration units have been mapped. The scivil register» with $47 \mathrm{in}$ - and 37 out-migrants is not counted here, as it is not divided into language groups. The same is the case for a few migrants belonging to different free churches and to other religions.

Sources: The migration registers in the parish archives.

$1901-05$ and $1949-53$. The results are shown on the maps in figures $4-7$ and in table 2.

In the years 1866-70 Kokkola had a net gain of 80 migration units from neighbouring areas and a somewhat greater loss to more distant towns and cities - a normal picture of a small stagnating commercial town. The language situation is scarcely affected by the small loss (the migration exchange with "Finnish-speaking" towns at that time may include Swedish-speaking persons because of the presence in some cases of Swedish-speaking minorities).

During the following thirty-five years until 1901-05 Kokkola has improved its migration balance. On the local level this period shows unchanged relations to the Swedish-speaking area compared with 1866-70, but the net gain from the Finnish-speaking area is more than doubled. The long-distance exchange has changed from deficits of -38 and -53 to gains of +5 and +41 . The sum of the migration exchange of Kokkola with the Swedish-speaking areas is 
Figures 4-7. The net migration exchange of Kokkola/Gamlakarlepy with the hinterland in $1866-1870$ and $1901-1905$ as well as of Swedish and Finnish parishes in 1949-1953.

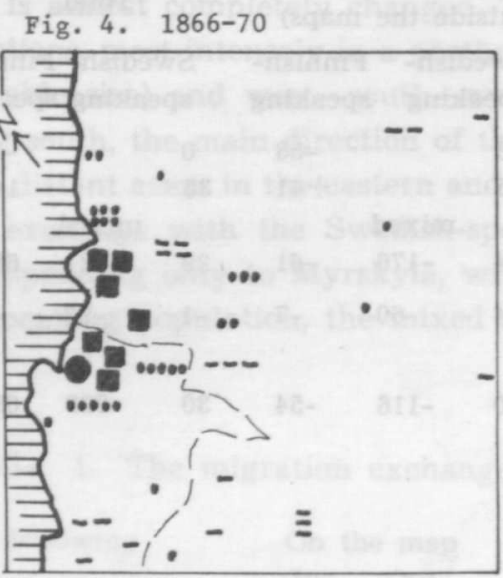

Fig. 6. Swedish parish

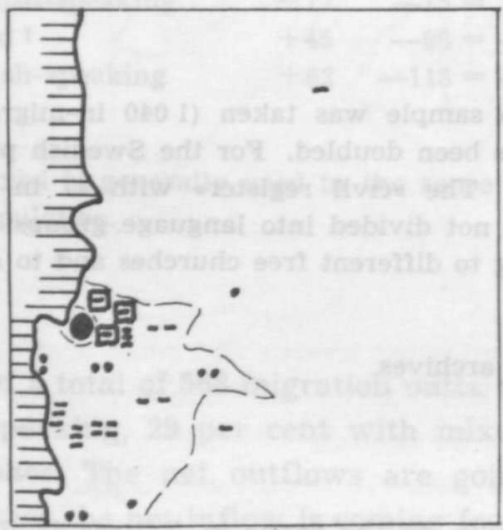

- A net gain of 1 migration unit

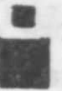

A net gain of 10

A net gain of 100

- A net loss of 1

曰 A net loss of 10

A net loss of 100
Fig. 5. 1901-05

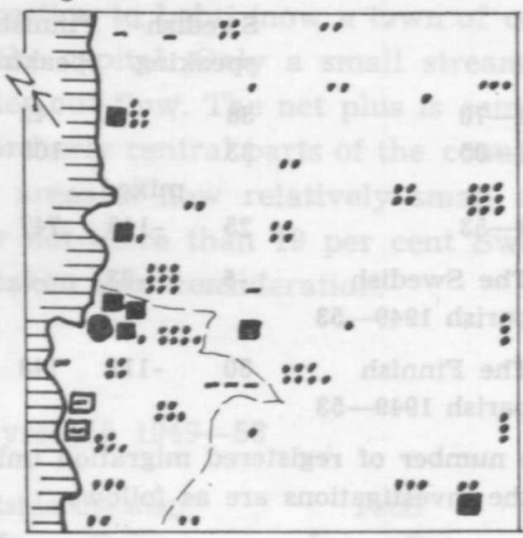

Fig. 7. Finnish parish

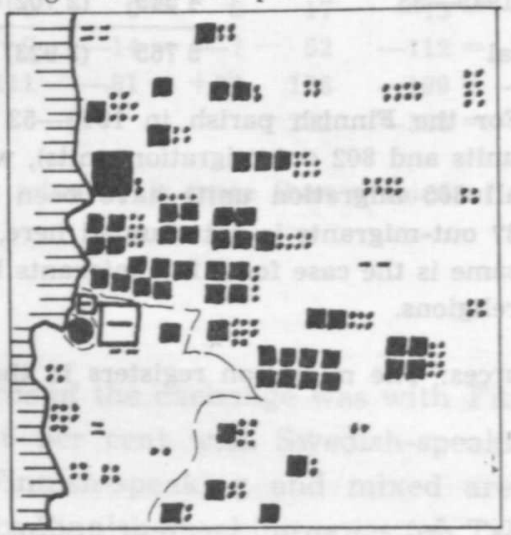

migration units

migration units

migration unit

migration units

migration units

+-0 in $1866-70$. In $1901-05$ it improved to +38 , while the exchange with the Finnish-speaking areas went up from -11 to +149 . The relation between the exchanges of Kokkola with the Swedish-speaking and with the Finnish- 
speaking areas has, as can be seen, greatly changed and in $1901-05$ the gain from Finnish-speaking areas is 111 migration units larger than the gain from Swedish-speaking areas. This corresponds to $4.5 \%$ of the population in the year 1900 and thus signifies a considerable change in the relation between the two language groups in a short time.

During the years $1949-53$ the town had a small gain from the nearby Swedish-speaking area, a very big gain from the Finnish-speaking part of the influence field a substantial loss to the now suburban parish of Karleby (Kaarlela). ${ }^{7}$ Over longer distances Kokkola lost people to Finnish-speaking areas, but even more to mixed areas.

For this period and for this town it is, however, possible to split the migrant population in two language groups, one belonging to the Swedish, the other to the Finnish parish. In this way a more exact estimation of the movements of the two language groups is possible. The results are shown on the maps in figures 6-7 and in the table. The two migrant populations generally keep to themselves in their own territories, but with a slight tendency for the Finnishspeaking to penetrate the other side. The Swedish parish in Kokkola has a balanced net migration result towards the rest of the country's Swedishspeaking parts, a heavy loss to the mixed areas (the suburban Karleby and some major cities) and also a small loss to the Finnish-speaking parts of the country.

The Finnish parish has a gain from nearby Swedish-speaking areas, heavy losses to suburban Karleby/Kaarlela and to distant mixed cities. There is further a very big gain from the Finnish-speaking trading area, where it has a dominating urban influence and a loss to distant areas - in this case especially to Tampere/Tammerfors, Oulu/Uleåborg, Lahti/Lahtis and to Lappeenranta/Villmansstrand - all of which are at a higher position in the urban hierarchy.

The resulting sum for the Swedish parish is a deficit of -102 and a gain for the Finnish parish of +496 migration units. Emigration to Sweden precisely during these years, mostly affecting the Swedish-speaking population, should also be considered in connection with these figures. On realizing all these facts, it is not unexpected that the proportions between the language groups changed rapidly and strongly.

The influence of migration on the language situation in southwestern Ostrobothnia

A sequence of municipalities are here investigated: The small town of Kristinestad, the parishes of Lappfjärd and Isojoki.

7 In 1900 Karleby had a Finnish-speaking minority of 7.5 per cent, which in 1950 had risen to 35.1 per cent. 
First a look will be taken at the development of the migration and language situation in Kristinestad, which has a geographical position and a situation in some ways resembling that of Kokkola. A picture of the spatial situation for the period $1901-05$ is given by the map in figure 8 . Table 3 shows the net migration for the town during four periods between 1826 and 1953. Figures are given for short and long distances, which are again divided into language areas. There have been gains form short distance migration during all four periods and for both language groups. The gains from Finnish-speaking areas, however, increase with time from $22 \%$ and $33 \%$ to $46 \%$ and $57 \%$. The long-distance table is more heterogeneous, but the net result with Swedishspeaking areas shows losses for all periods but the first, whereas the exchange with Finnish-speaking areas results in more gains than losses. The conclusion

Figure 8. The net migration exchanges of Kristinestad with the hinterland, $1901-1905$.

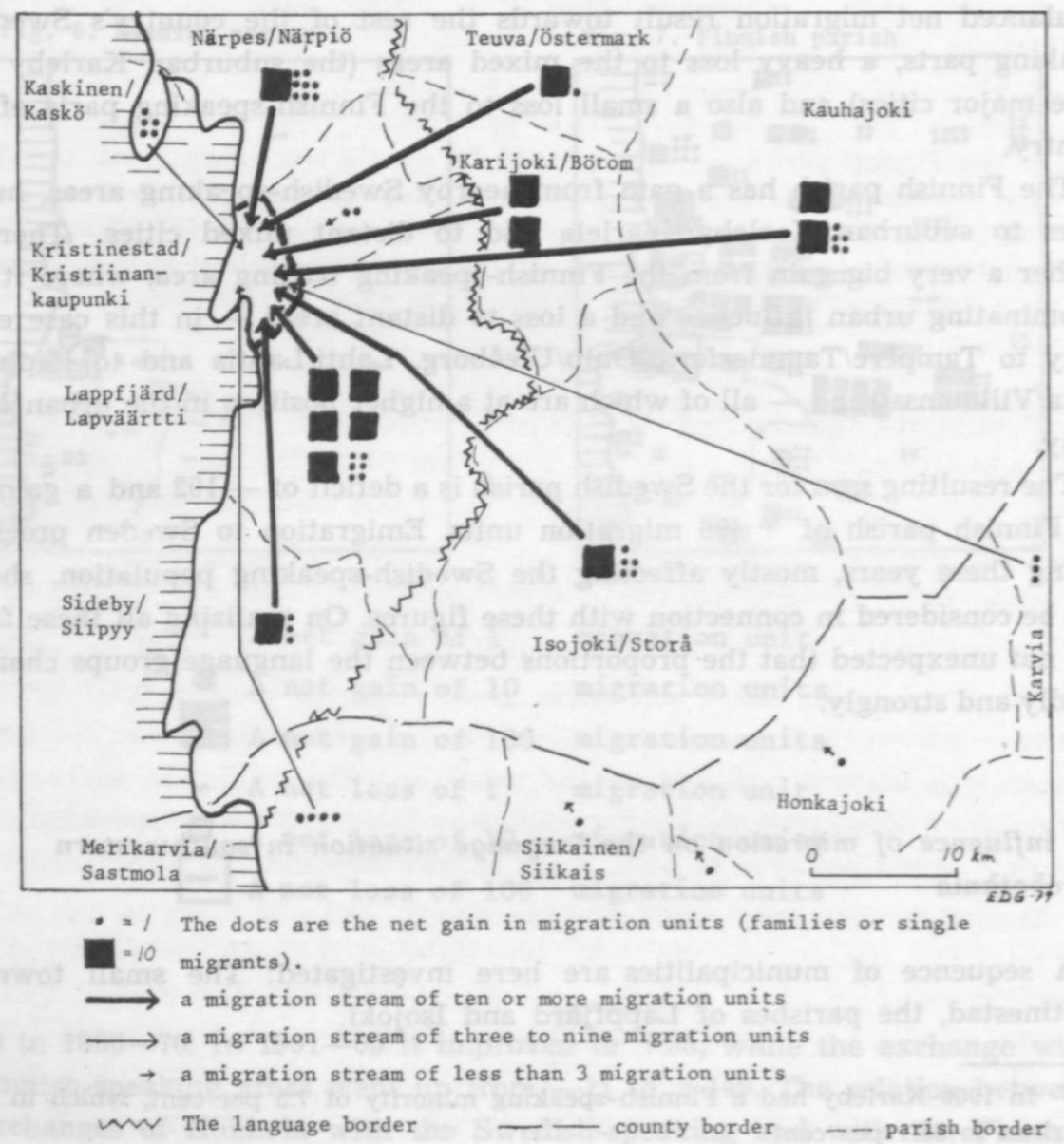


of the table is that during the first period investigated the Swedish-speaking population and population exchange dominated, but later the inflow from Finnish-speaking areas increased successively. The effect on the language groups of the town can be seen in figure 17 .

The number of in- and out-migrants investigated are (in migration units) 827 for $1826-30$; 876 for $1866-70$; 664 for $1901-05$ and 608 for $1949-53$, together a sum of 2975 migration units (families and single migrants). The population of Kristinestad was about 1200 in 1820, 2400 in 1860, 2568 in 1900 and 2872 in 1950 .

$\mathrm{Table} 3$. Kristinestad's net migration during four periods between 1826 and 1953 . Net result with:

The hinterland

(on the maps)

Time

period

speaking speaking

Long distance areas

(outside the maps)
Total

Swedish- Finnish- Differspeaking speaking ence speaking speaking

\begin{tabular}{ccrr}
$1826-30$ & 64 & 18 \\
$1866-70$ & 70 & 34 \\
$1901-05$ & 95 & \multicolumn{3}{r}{81} \\
& \multicolumn{3}{c}{ mixed } \\
$1949-53$ & 39 & 1 & 53
\end{tabular}

\begin{tabular}{rrr}
44 & & 10 \\
-65 & & -2 \\
-48 & & 43 \\
\multicolumn{3}{c}{ mixed } \\
-8 & -58 & -18
\end{tabular}

\begin{tabular}{rrrr}
108 & 28 & 80 \\
5 & 32 & -27 \\
47 & 124 & -77 \\
\multicolumn{3}{c}{ mixed } \\
31 & -57 & 35 &
\end{tabular}

The »hinterland" consists here of 5 Swedish-speaking and 10 Finnishspeaking parishes. "Mixed" areas should include those with language minorities of more than a third of the population (an exception is made for the Helsinki suburb. Helsinki parish with a Swedish-speaking population of only $26 \%$ in 1950). 8

The next in the line - the parish of Lappfjärd - is situated between Kristinestad and the language border. The map of the net migration in $1901-05$ for Lappfjärd (Figure 9) gives an impressive picture of migration by stages from the more distant Finnish-speaking parts to Lappfjärd and from Lappfjärd to Kristinestad. Table 4 gives us these figures as well as those of the longdistance movers (here those outside the map).

Heavy losses to Swedish-speaking areas and very high gains from Finnishspeaking areas resulted at that time in rapid changes in the proportions between the language groups (Figure 17).

8 The mixed areas here include the cities of Helsinki with suburbs Helsinki parish/ Helsinge, Esbo/Espoo and Grankulla/Kauniainen; Turku/Åbo and Vaasa/Vasa, the towns of Kokkola/Gamlakarleby with suburban Karleby/Kaarlela, Kaskinen/Kaskö, Porvoo/ Borgå with Borgå parish and the parishes of Pohja/Pojo, Lapinjärvi/Lappträsk, Ruotsinpyhtää/Strömfors, Pargas/Parainen and Sideby/Sipyy. 
Table 4. The migration exchange of Lappfjärd, 1901-05

\section{Short distance migration}

Swedish- Finnishspeaking speaking areas

In-migration

Out-migration

Net-migration

83
-138
-55

\section{Long distance migration}

Swedish- Finnish speaking speaking areas areas

$\begin{array}{rr}159 & 22 \\ -45 & -29 \\ 114 & -7\end{array}$

\section{Total}

Swedish- Finnishspeaking speaking areas areas

$\begin{array}{rr}105 & 186 \\ -167 & -54 \\ -62 & 132\end{array}$

What is then the case with Isojoki (Figure 10)? The parish loses migrants to both Kristinestad and to Lappfjärd over the language border, but the map shows that in other directions Isojoki gets net plus from most of its neighbours. That results in a net gain of 39 from the Finnish-speaking neighbourhood -

Figure 9. The net migration exchange of Lappfjärd with its surroundings, $1901-1905$.

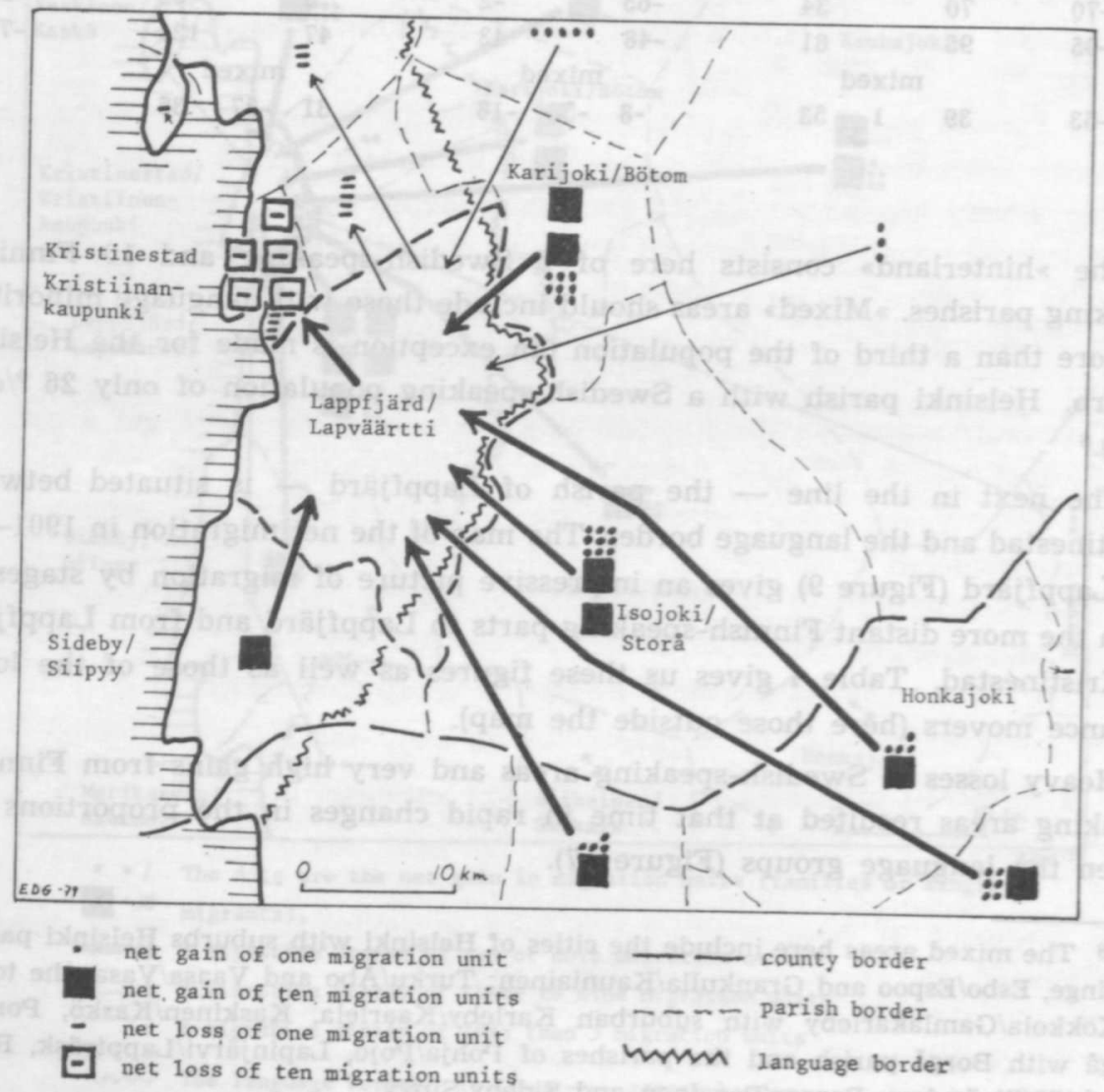


Figure 10. The net migration exchange of Isojoki/Storå with its surroundings, 1901-1905. For explanations of symbols, see figures 8 and 9 .

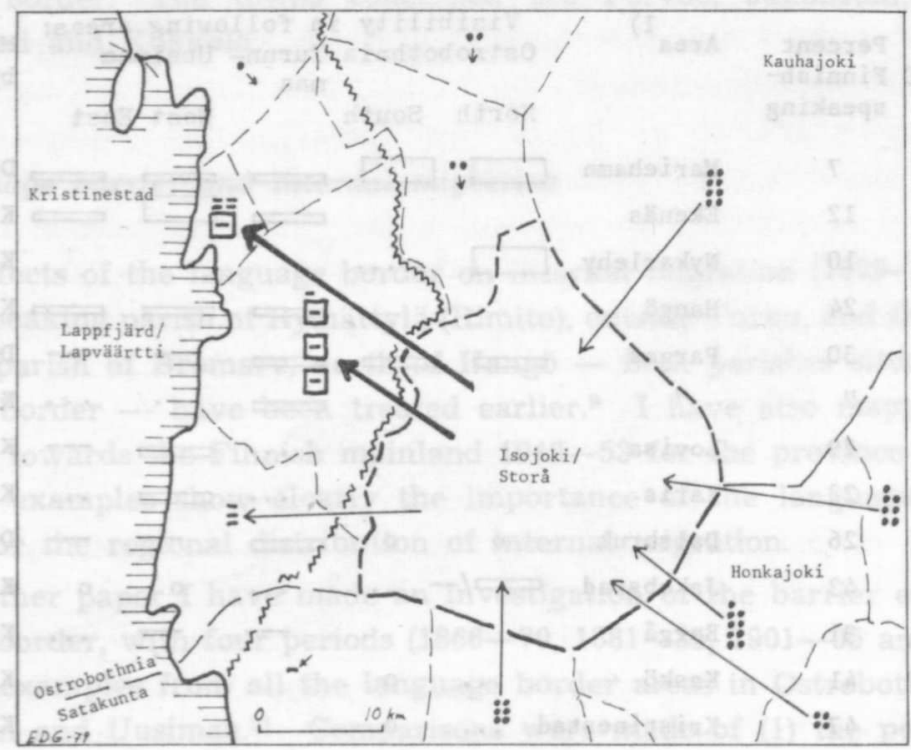

and a deficit of -48 to the Swedish parishes of Lappfjärd, Kristinestad and Sideby. The exchange with the more distant Swedish-speaking parts of the country results in a deficit $(+5-14=-9)$ and the exchange with the more distant Finnish-speaking parts gives a small gain $(+39-33=6)$. Isojoki had at that time a Swedish minority of 1.6 per cent, too low a percentage to explain from a minority point of view the losses of 57 migration units to Swedishspeaking areas. The loss is then nearly compensated by the gain of 45 migration units from Finnish-speaking areas.

\section{The language barrier influencing internal migration and emigration}

Birthplace fields as indicators of the influence of language on migration

It can be said that the mapping of the birthplaces of a population reveals all migrations during the life of the persons involved, up to the time of the investigation.

The mapping work of Klövekorn (1960) and that of the present author (1960 a) together cover the birthplace fields for most of the small and middlesized towns and market towns in the language border region in Finland, using material from the census of 1950 . Table 5 shows the extent that birthplace fields are influenced by the language border. In most cases the more distant 
Table 5. Birthplace fields of some Finnish towns and the influence of the language border in 1950.

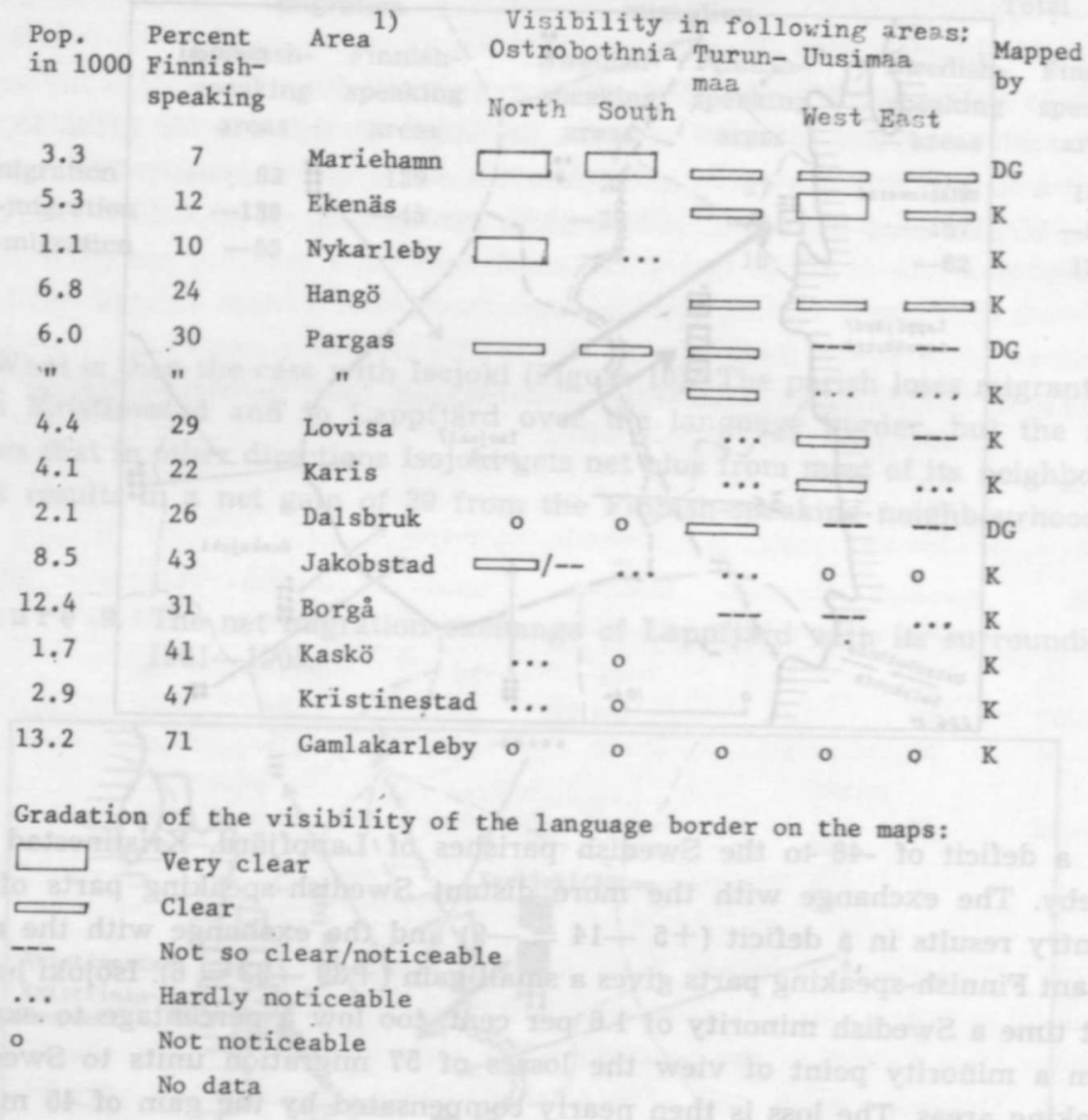

The population and the percent of Finnish-speaking are from the 1950 census

$\mathrm{K} \quad=$ in Klöverkorn (1960), chapter VI

DG = in De Geer (1960a), see separate maps, Fig. 2a, 2b, 2c.

1 The names of the urban places are in Finnish: Maarianhamina, Tammisaari, Uusikaarlepyy, Hanko, Parainen, Loviisa, Karjaa, Taalintehdas, Pietarsaari, Porvoo, Kaskinen, Kristiinankaupunki and Kokkola.

parts of the border were not mapped by Klövekorn - indicated by sno data». The total populations of the towns and market towns as well as the size of the Finnish-speaking part, are also shown.

The table shows a clear tendency for towns with a predominating Swedishspeaking population - Mariehamn, Ekenäs and Nykarleby - to have the most marked drops in the birthplace influence fields at the language border. In accordance with this is the fact that towns with nearly equal Swedish- and 
Finnish-speaking populations show no or scarcely noticeable differences concerning the intensities of the birthplace influence fields with reference to the language border. The towns concerned are Porvoo, Jakobstad, Kaskinen, Kristinestad and Kokkola.

The language barrier and internal migration

The effects of the language border on internal migration (1949-53) for the Finnish-speaking parish of Rymättylä (Rimito), outside Turku, and the Swedishspeaking parish of Bromarv, north of Hangö - both parishes situated on the language border - have been treated earlier. ${ }^{9}$ I have also mapped the net migration towards the Finnish mainland $1949-53$ for the province of $\AA$ land. ${ }^{10}$ All three examples show clearly the importance of the language border in Finland for the regional distribution of internal migration.

In another paper I have made an investigation of the barrier effect of the language border, with four periods $(1866-70,1881-85,1901-05$ and $1949-53)$ and with examples from all the language border areas in Ostrobothnia, Varsinais-Suomi and Uusimaa. ${ }^{11}$ Comparisons were made of (1) the percentage of migration over the language border with (2) the percentage of the length of that part of the border which is situated opposite areas with the wother" language and (3) with the percentage of the population belonging to the minority language groups. Briefly, the results were as follows:

In general, it can be said that there are gains for the Swedish-speaking coastal municipalities from their Finnish-speaking, more inland, neighbours. The important factor here for the Swedish-speaking municipalities seems to be the relative location in co-operation with the higher degree of centrality for some of them. There is a slight co-variation between the percentage of migration over the language border and the length of the border opposite the "other" language, whereas the co-variation regarding the size of the language minorities is negligible.

In co-operation with Holger Wester the author has investigated the migration contacts over the language border for fourteen country parishes in Ostrobothnia, seven Finnish-speaking and seven Swedish-speaking. ${ }^{12}$ The periods studied are $1866-70,1881-85$ and $1901-05$. Briefly, the result is that there are only small deficits in the contacts (= migrations) over the language border at the most northerly and southerly parts of the border, whereas there are big deficits in the middle part.

9 De Geer (1960a), see separate maps, figures $4 a, 4 b$.

10 De Geer (1960b), map 11, p. 112.

11 De Geer (1975) passim.

12 De Geer/Wester (1975), chapter 4.5. pp. 68-72 and figures $13.1-6$ in the map appendix 1. 
In the study of labour migration and emigration from the province of Vasa, Holger Wester and I also investigated the effects of the language border on emigration during $1861-1890 .{ }^{13}$

Regarding emigration to Russia, the Swedish/Finnish language border played an insignificant role or no role at all (op. cit., the maps pp. 54-55). As to emigration to America, the language border was significant in the earlier phases $(1861-75)$ (op. cit., pp. $60-61)$. The importance of the language border varies widely when considering emigration to Sweden (op. cit., the maps pp. 58-59). Here the border has a dominating role in its middle parts, a significant role in the south and practically no role at all in the north.

It was possible to show that the barrier effect differences probably depend on differences in the internal migration pattern. ${ }^{14}$ Internal migration was very restricted in the middle parts, partly restricted in the northern area and not restricted in the south. ${ }^{15}$

The conclusions of the above-mentioned investigations are as follows: The barrier effect and the diffusion of emigration can differ both regionally and with time. Further, the barrier effect on emigration seems to depend on the language and country combinations involved. For instance, until after 1968 emigration to Sweden interested the Swedish-speaking more than others. Also emigration to America concerned the Swedish-speaking more than the Finnish-speaking population in the earlier phases (1861-75), which is largely explained by the fact that the first ideas about emigration to America mainly came from Finns in Sweden, and that emigration to America in the early days was via Sweden (and Norway). In this connection it is interesting to compare the emigration to Russia.16 The Finnish-Swedish language border obviously did not affect the regional distribution of this emigration. In this case the Russian language was no factor of importance. This is in accordance with the observations above.

I have also studied the migration exchange of the Finnish parish in Stockholm with Finland during $1811-20,1866-70$ and $1901-05.17$ In spite of both languages being represented among the parishioners, a higher portion of the population of the Swedish-speaking areas in Finland emigrated to Stockholm than that from the Finnish-speaking parts. This applies to all three time periods.

13 De Geer-Wester (1975), pp. 53-88, and the map appendices.

14 De Geer-Wester (1975), pp. 68-72, and maps fig. 13 p. 113.

15 In sections 1.2. and 1.3. in this paper it has been possible to give an explanation to the absence of barrier effects in the south and the north. It is the extension of the urban influence fields of Kristinestad and Kokkola over the language border which implicates the migration.

16 De Geer-Wester (1975), pp. $54-55$.

17 The map of the migration exchange for $1901-05$ is in De Geer (1977), p. 82. 
Figure 11-12. Emigration to Sweden in 1931 and 1938 in relation to the population of the provinces. For explanation of the symbols, see figures 13 and 14.
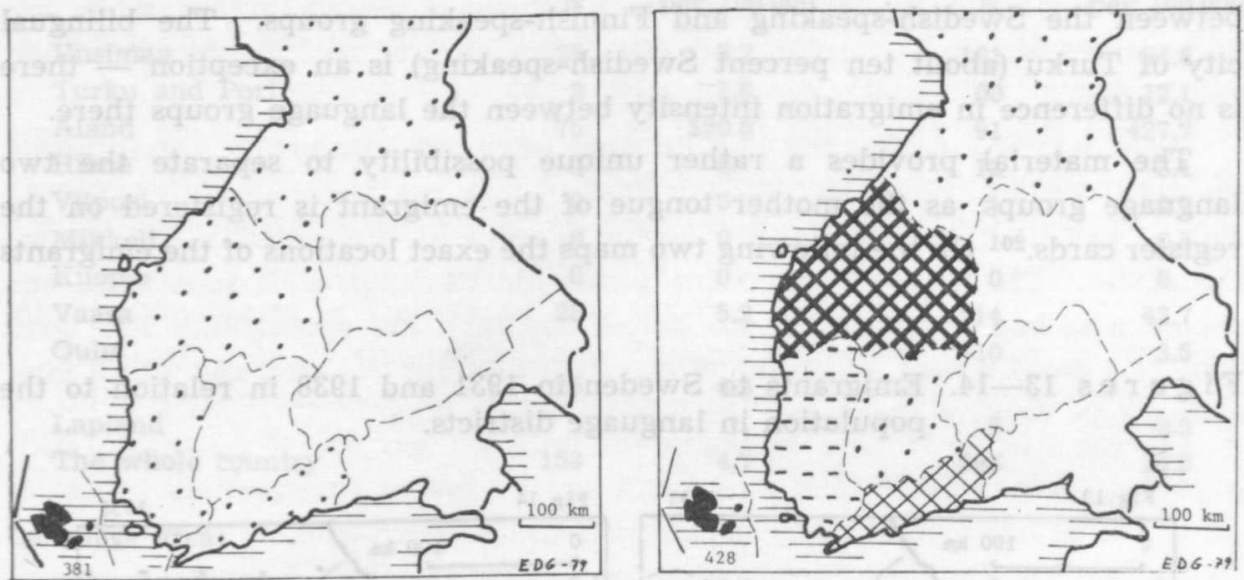

Source: Statistical yearbooks, 1932, tab. 57 and 1939 tab. 61.

Emigration from Finland to Sweden in 1931 and 1938 and the language groups in Finland

This investigation concerns persons in Finland who received passports to Sweden in the years 1931 and 1938. ${ }^{18}$ The task is to find out possible differences between the two language groups in their inclination to emigrate. Of the two years chosen, 1931 is a year of small mobility abroad (this is valid for both Finland and Sweden), while 1938 - the last year of peace before the Second World War - has a fairly considerable emigration to Sweden.

First, two maps showing the relative distribution of emigration on the province level. The map of 1931 tells us that emigration from Alland was high. The second map (1938) also indicates a high emigration percentage from Åland besides showing that three of the south-western provinces have been involved in the emigration movement (Figures 11, 12).

When a differentiation in language groups is made we get the results as shown in table 6 and in the two following maps (Figures 13 and 14). ${ }^{19}$ The picture is much more sharp and clear and demonstrates convincingly the importance of language for the regional distribution of emigration to Sweden

18 The source material used has been card registers of the emigrants in the Archive of the Central Statistical Office in Helsinki.

19 The figures of Uusimaa and Helsinki in 1938 are too low here, caused by gaps in the registers at the Central Statistical Office in Finland. The language border is shown on the maps to demonstrate the main distribution of the two groups. 
(and also the negative effects of using the province level for this sort of investigation).

An interesting fact is that even in 1931, when the overall figures of emigration from Finland to Sweden were negligible, there was a clear distinction between the Swedish-speaking and Finnish-speaking groups. The bilingual city of Turku (about ten percent Swedish-speaking) is an exception - there is no difference in emigration intensity between the language groups there.

The material provides a rather unique possibility to separate the two language groups, as the mother tongue of the emigrant is registered on the register cards. ${ }^{20}$ On the following two maps the exact locations of the emigrants

Figures 13-14. Emigrants to Sweden in 1931 and 1938 in relation to the population in language districts.
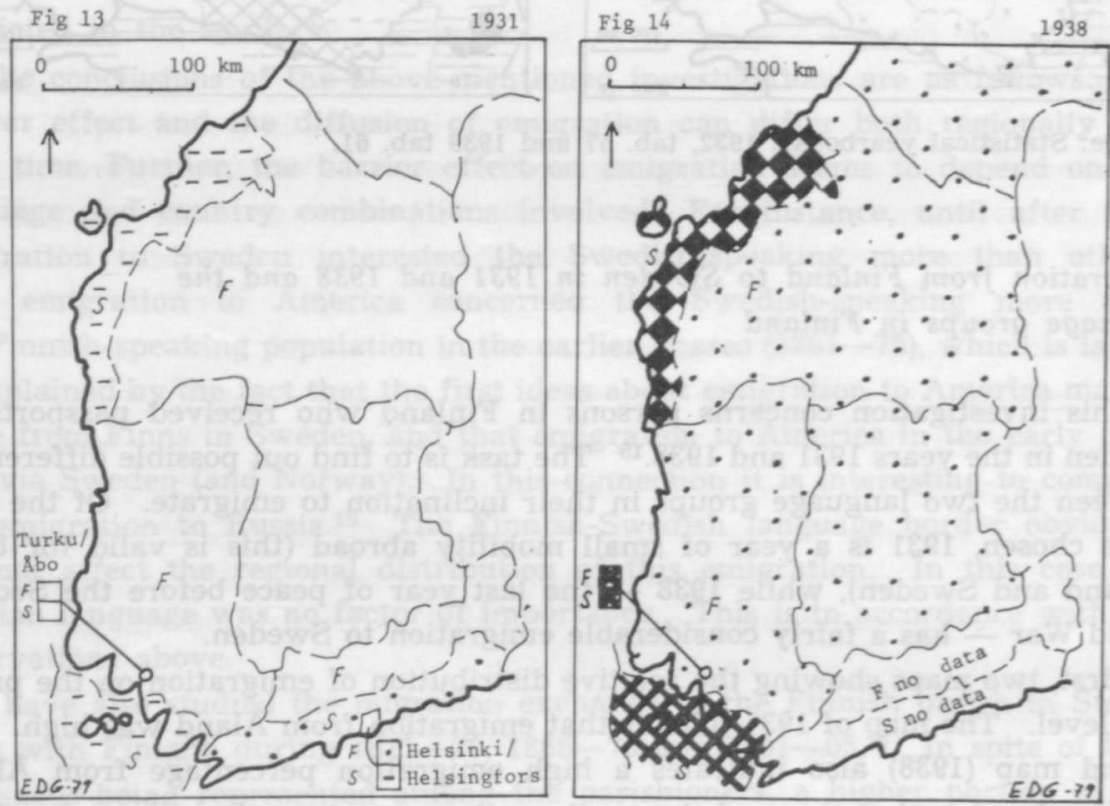

Emigrants per 100000 inhabitants

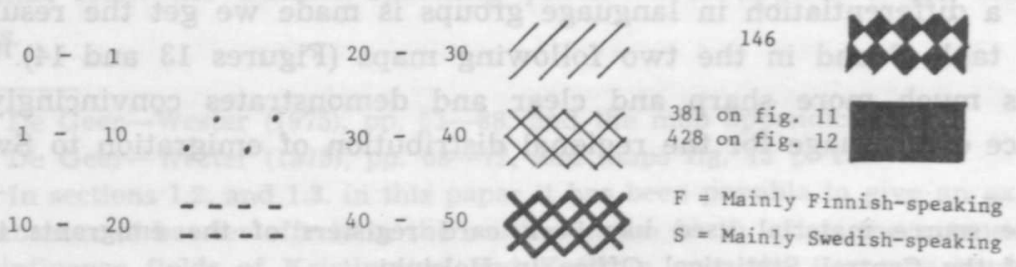

Source: Passport registers of emigrants in the central office of statics, Helsinki.

20 An example of the register-cards is shown in appendix 2. 
T a b le 6. Emigrants to Sweden in 1931 and 1938

In provinces and language areas

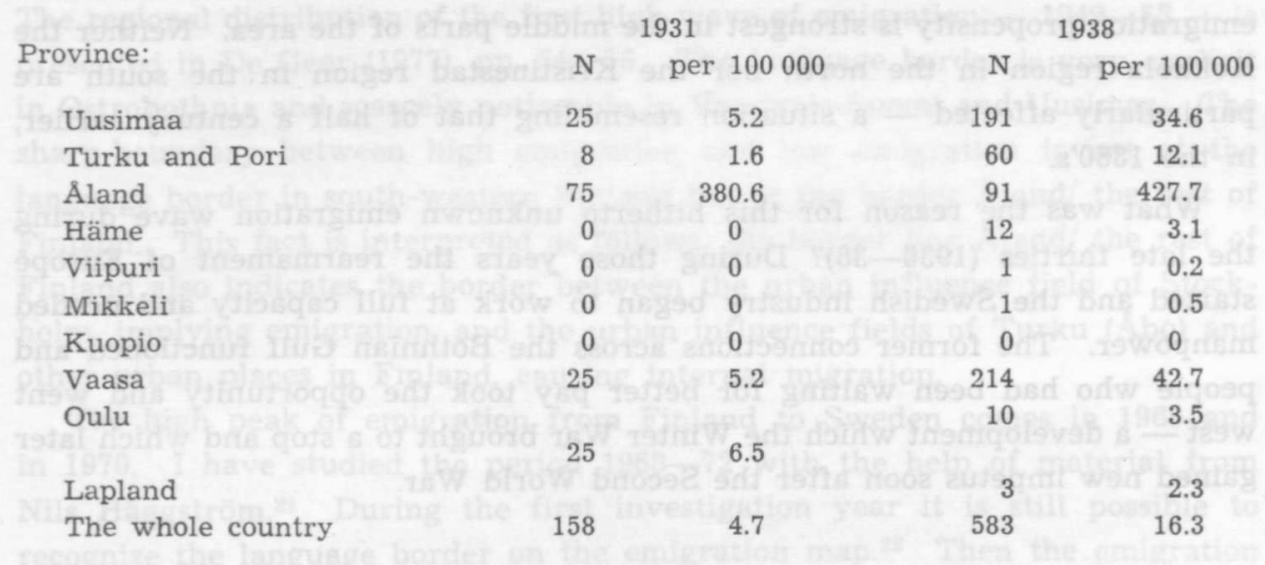

Language area:

$\begin{array}{lrccc}\text { Helsinki, Swedish part } & 91 & 13.7 & ? & ? \\ \text { Helsinki, Finnish part } & 141 & 8.9 & ? & ? \\ \text { Uusimaa, Swedish part } & 2 & 1.8 & ? & ? \\ \text { Uusimaa, Finnish part } & 1 & 0.7 & ? & ? \\ \text { Turku, Swedish part } & 0 & 0 & 52 & 41.8 \\ \text { Turku, Finnish part } & 0 & 0 & 312 & 45.5 \\ \begin{array}{l}\text { Turku and Pori, } \\ \text { Swedish part }\end{array} & 3 & 10.0 & 12 & 41.8 \\ \begin{array}{l}\text { Turku and Pori, } \\ \text { Finnish part }\end{array} & 2 & 0.5 & 9 & 2.3 \\ \begin{array}{l}\text { Vaasa, Swedish part } \\ \text { Vaasa, Finnish part }\end{array} & 21 & 15.5 & 202 & 146.5 \\ \begin{array}{l}\text { Swedish speaking } \\ \text { areas, total }\end{array} & 3 & 0.9 & 9 & 2.5 \\ \begin{array}{l}\text { Finnish speaking } \\ \text { areas, total }\end{array} & 101 & 28.9 & 324 & 162.0 \\ & & & & 764 \\ \end{array}$

Sources: For provinces: The Statistical Yearbooks 1932 table 57 and 1939 table 61 . For language areas: the annual registers in the archives of the Central Statistical Office in Helsinki.

1 With Helsinki parish

2 With Maaria parish
3 Åland included

4 Without Uusimaa and Helsinki

to Sweden are marked (Figures 15 and 16). The investigation years are the same as before. As mentioned before, the registers for the province of Uusimaa are incomplete but, as the hiatus seems to be at random, it will not influence the relations between the groups in the province.

To mention some results, most of the emigrants have come from areas dominated by their own language. More Finnish-speaking emigrants have 
come from the language-minorities in the Swedish-speaking areas than viceversa. The only area with a Finnish-speaking majority and with a high emigration rate is the city of Turku in 1938. In Swedish-Obstrobothnia the emigration propensity is strongest in the middle parts of the area. Neither the Kokkola region in the north nor the Kristinestad region in the south are particularly affected - a situation resembling that of half a century earlier, in the 1880's.

What was the reason for this hitherto unknown emigration wave during the late thirties (1936-38)? During those years the rearmament of Europe started and the Swedish industry began to work at full capacity and needed manpower. The former connections across the Bothnian Gulf functioned and people who had been waiting for better pay took the opportunity and went west - a development which the Winter War brought to a stop and which later gained new impetus soon after the Second World War.

Figures 15-16. Emigrants to Sweden in 1931 and 1938 from the provinces of Uusimaa (Nyland), Turku and Pori and Vaasa (Vasa). For 1938 the provinces of Häme and Oulu and Lapland are also included.

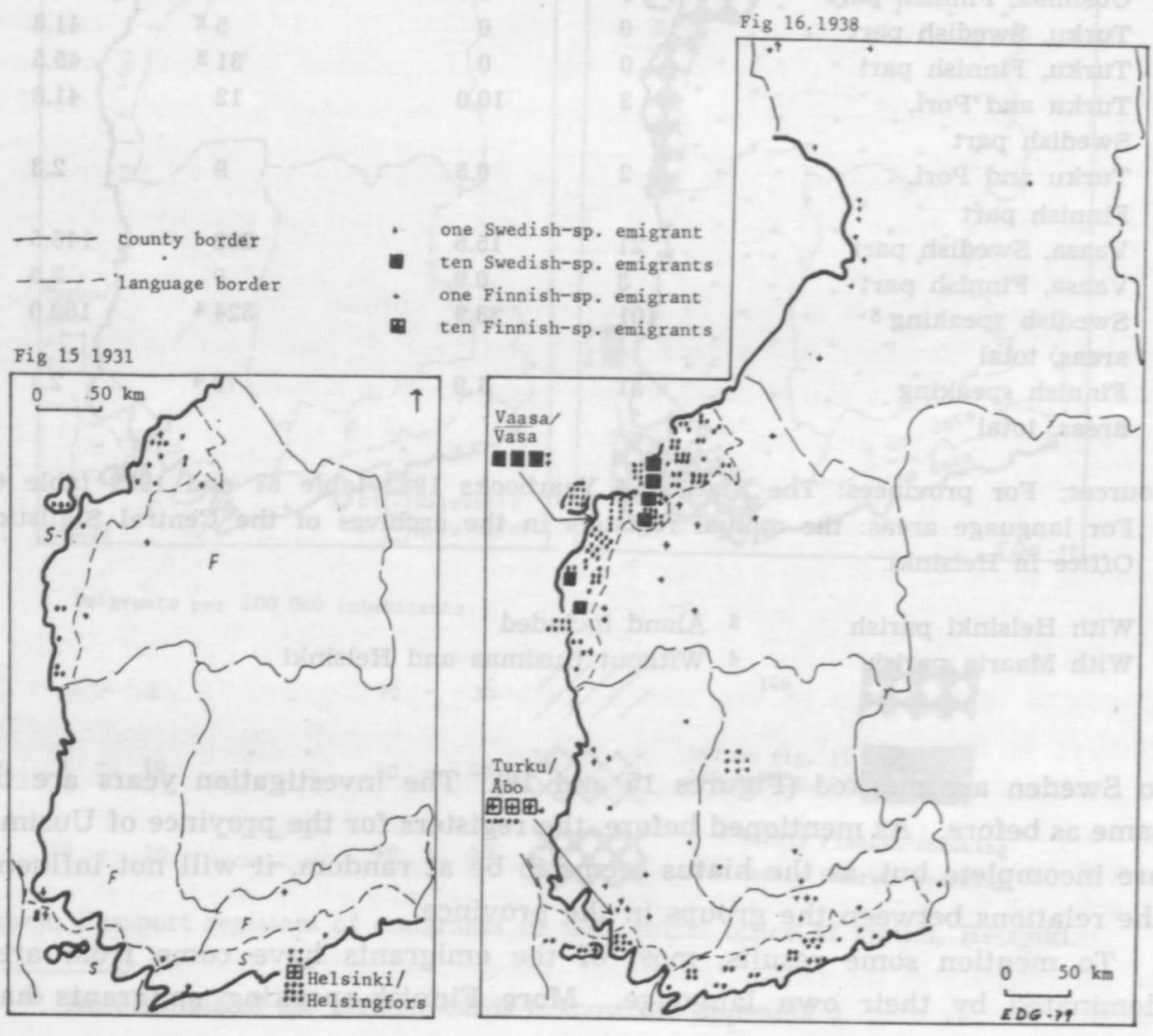


Emigration to Sweden in $1949-53$ and in $1968-72$

After the Second World War Finnish emigration to Sweden accelerated. The regional distribution of the first high wave of emigration - 1949-53 - is presented in De Geer (1977), pp. 54 56. The language border is very explicit in Ostrobothnia and scarcely noticeable in Varsinais-Suomi and Uusimaa. The sharp boundary between high emigration and low emigration is not at the language border in south-western Finland but at the border $\AA$ land/ the rest of Finland. This fact is interpreted as follows: the border line Åland/ the rest of Finland also indicates the border between the urban influence field of Stockholm, implying emigration, and the urban influence fields of Turku ( $\AA$ bo) and other urban places in Finland, causing internal migration.

The high peak of emigration from Finland to Sweden comes in 1969 and in 1970. I have studied the period 1968-72 with the help of material from Nils Häggström. ${ }^{21}$ During the first investigation year it is still possible to recognize the language border on the emigration map. ${ }^{22}$ Then the emigration wave 'drowns' the border and reaches its highest peaks inland and in the north. Exactly the same happened with emigration to America in 1871-1890 (cf. 2.3.).

With a regional analysis I can demonstrate that just around 1969 the urban influence fields of the five most important and expansive towns in the area have gained so much strength in directing internal migration that they also command over the regional distribution of emigration. ${ }^{23}$

\section{Summary}

The first part of the paper demonstrates how, in both rural and urban areas, a language border can be affected by migration streams originating in urban centres. The results are based on the mapping of the migration of 9225 migration units.

For the rural areas the migration was largely by stages. In-migrating, Finnish-speaking people replaced out-migrating Swedish-speaking people who were moving to more central places (or to Sweden). This caused rapid changes in the proportions between the language groups. However, in the case of Lappfjärd in 1949-53 the Finnish-speaking must also have moved on to Kristinestad in roughly the same number as they moved in to the parish from the interior because the language relations remain nearly status quo (Figure 17 d.).

For Myrskylä the Swedish-speaking majority of 64 per cent in 1880 has changed to a minority of 19 per cent in 1950 (Figure 17 a.). The migration

21 Häggström (1972), figures 17-19, pp. 65-67. See also Majava (1975).

22 De Geer (1977), pp. 56-62.

23 De Geer (1977), the diagrams, figures $11 \mathrm{~b}$, c, d, and e with comments pp. 58-61. 
Figure 17. The language of the population in the investigation areas.

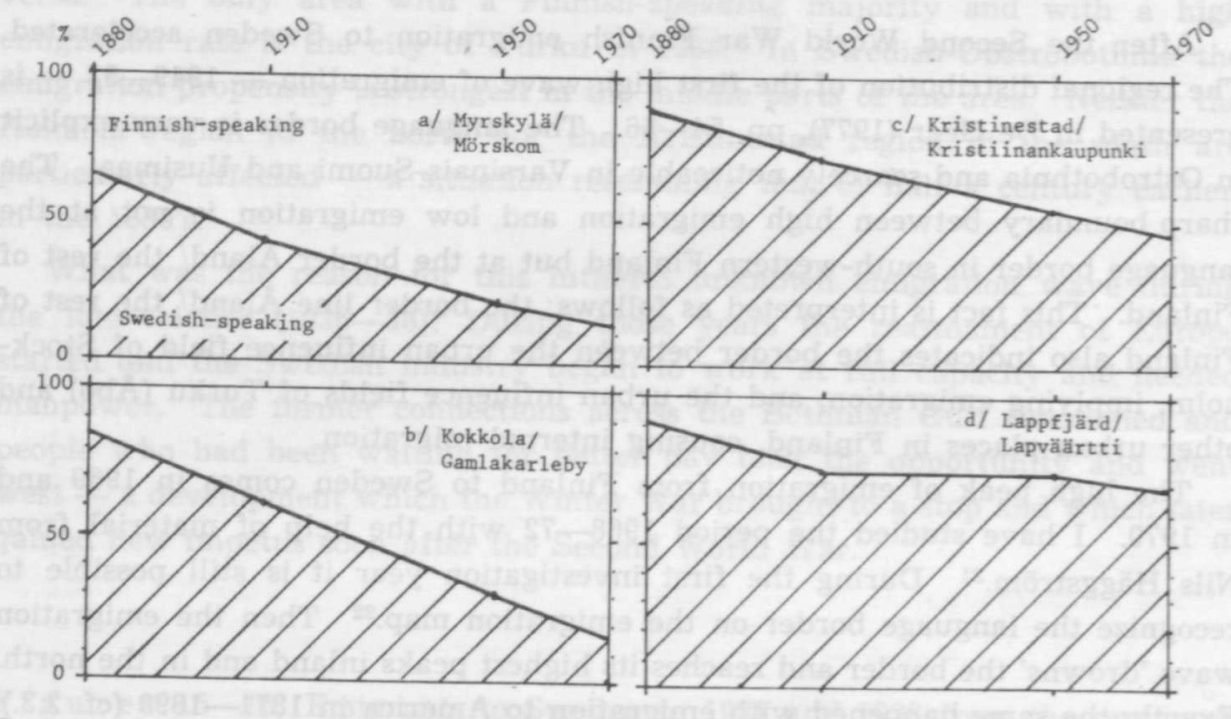

Sources: 1880, census. The population in the parish register.

1910, census. "Present population».

1950 , census. "Resident population».

1970, Population census.

streams have gone from the Finnish-speaking interior to Myrskylä and from Myrskylä to the urban centres of Borgå, Lovisa, Lahti and Helsinki, directly or stepwise.

Concerning urban centres, Kokkola demonstrates a language situation which becomes reversed - from $84 \%$ Swedish-speaking in 1880 to $83 \%$ Finnish-speaking in 1970 (Figure 17 b.), and the reason lies in the fact that more than four-fifths of its hinterland is Finnish-speaking.

Kristinestad has had a lower degree of expansion and more than a third of its hinterland is Swedish-speaking, so the transformation has gone slower from $88 \%$ to $46 \%$ Swedish-speaking (Figure $17 \mathrm{c}$.).

At some (other) parts of the language border there are no, or only small, signs of change regarding the language situation. In a previous work - De Geer-Wester (1975), pp. 70-72 - this is demonstrated for the Malax-Laihela region in Ostrobothnia for the periods 1866-70, 1881-85 and 1901-05 and the explanation is to be found in the proved strong deficits in the migration exchange over the language border. With that we are in the second part of the paper.

The second part of this paper deals with the threshold effects of the language border. The background is that the diffusion of information about the possibility of profitable employment is not spread uniformly, thus effecting migration destinations. 
In a test of using birthplace fields as indicators of the threshold effects of the language border, the result showed clearly that the effects were to a rather high degree dependent on the proportions of the language groups in the investigated urban places.

Many examples of mapping by the author of internal migration and emigration are referred to and most of them give good evidence of the importance of the language border for the regional distributions of internal migration and emigration. One restriction to the rule is that the barrier effect depends on the phase in the emigration diffusion cycle. The effect is present in the earlier phases - the introduction and the growth phases - as is illustrated by emigration to America in 1861-90 and emigration to Sweden in 1931, 1938, 1949-53, and in 1968-72. In the later phases - in the saturation phase and the first part of the regression phase - the language border is »overwhelmed" and the emphasis is on the other side of the border.

For the heavy emigration from Finland to Sweden after the Second World War it is demonstrated that the regional distribution with its sharp limit at the language border in Ostrobothnia in 1949-53 has its predecessor in the situation in 1938 and, to a lesser extent, as early as in 1931. The regional situation in 1938 continued, after a stop of nearly ten years during the Second World War and for a time thereafter, in the late forties and proceeded to 1969 whereafter the development went over to the next phase with the centre of gravity in the Finnish-speaking inland.

If the above demonstrated pattern holds, the situation after some time, when the present fairly high emigration has declined, should be back in the phase when the language border is again distinctly marked on the emigration map along most of its length. ${ }^{24}$

\section{Appendix 1. Other factors of significance to the proportions of the language groups}

The paper deals with the importance of the migration factor - both internal migration and emigration - for the changes of proportions between the language groups. This factor is, of course, not the only one of relevance, even if it undoubtedly is the most important one in the majority of the cases.

If, for instance, the populations have different nativity rates, this fact will affect the proportions of the language groups. Another factor is the choice of language made by the children of "mixed marriages».

24 It is possible but not very likely that the great mass of Finnish immigrants in Sweden will disturb the pattern to any greater extent. According to an investigation of Finnish return migrants from Gothenburg, they prefer to move to one or another of the urban places in the region of their birthplaces (De Geer, 1980, p. 17). 
In this connection it should be mentioned that Gunnar Fougstedt has investigated nativity among the two language groups as well as the question of the children's choice of language, for the period 1939-45. He comes to the conclusions that the Swedish-speaking population has lower nativity rates than the Finnish-speaking population, and that the percentage of Swedish-speaking children in mixed marriages is strongly correlated with the percentage of the Swedish-speaking population in the community. ${ }^{25}$

Fougstedt also found that the language of the mother is more important than that of the father: when the mother was Finnish-speaking, 65 per cent of the children were Finnish-speaking, and when the mother was Swedish-speaking, 49 per cent of the children spoke Swedish. The result of this was a loss of 3.3 per cent of the natural reproduction among the Swedes in Finland.

These results are due to the situation of the last fifty years, when the Swedish-speaking population has become a minority in the large coastal cities and their suburbs. In the nineteenth century, however, the situation was the reverse - the Swedish-speaking population was in the majority in most coastal towns and cities.

Another researcher, Karl-Erik Forsberg, has tried to calculate for the period 1961-70 to what extent the diminishing of the Swedish-speaking population in Finland depends on demographical factors or on people becoming Finnishspeaking. ${ }^{26}$ The calculations gave the result that for the years in question emigration was the main factor. For the internal migration factor, he has only studied the Swedish-speaking population, which in general had small losses. The internal migration of the Finnish-speaking people, which is more than equally important for the present question of the changing of proportions between the language groups, was not treated.

\section{Appendix 2. Emigration register card}

Emigration register cards were in use during the thirties (see p. 85). They were bilingual. The items registered were the sex of the emigrant, date of birth, home province and parish, date when the passport was issued and for what time it was valid. The reverse of the card gave information about civil status, mother tongue, religious community, country of destination, reason for journey, family members remaining in the country and names and dates of birth for accompanying children under 15 years.

25 Fougstedt (1951), pp. 111-112, 181-182.

This is valid for older times. For the time after the Second World War (1946-74) Fjalar Finnäs has found that there is no difference in nativity between the two language populations (Finnäs 1973).

26 Forsberg (1975), pp. 18-23. 

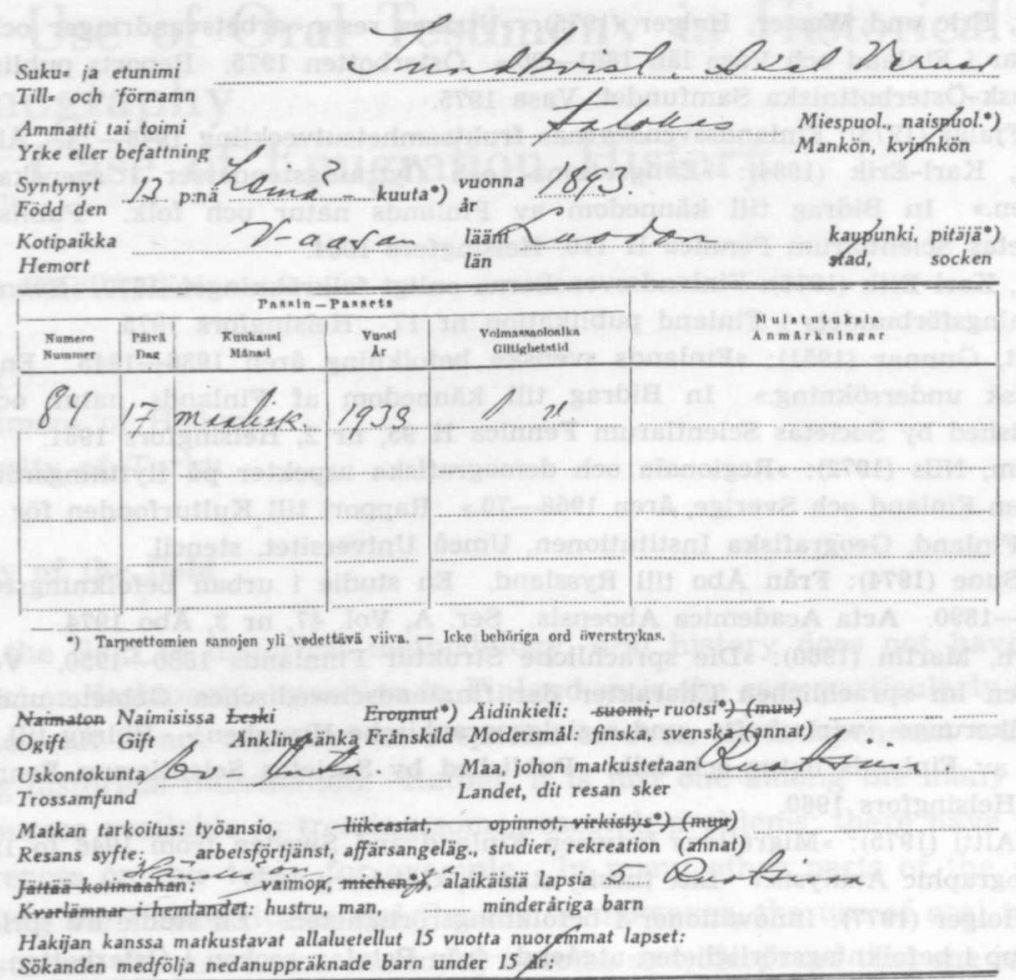

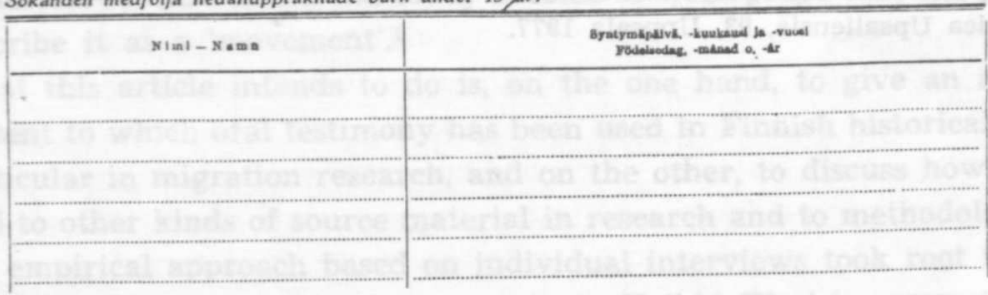

•) Tarpeetlomien sanojen yli vedettuiví vïva. - Icke behöriga ord overstrykas.

\section{References}

De Geer, Eric (1960a): "Migration in the Archipelago of South-western Finland During the Last Hundred Years.» In Fennia, 84, 1960.

De Geer, Eric (1960b): "Nettoflyttningsutbytet mellan Åland och Finland 1949-1953. In Åländsk odling. Årsbok 1960, Mariehamn 1960.

De Geer, Eric (1975): Språkgränsen som kontaktbarriär. Migration och emigration vid språkgränsen i Finland 1900 och 1950. Unpublished paper, Hist. inst., Uppsala 1975.

De Geer, Eric (1977): Migration och influensfält. Studier av emigration och intern migration i Finland och Sverige 1816-1972. Studia Historica Upsaliensia, 97, Uppsala 1977.

De Geer, Eric (1980): Finländare i Göteborg. Rapport. Göteborg 1980. 
De Geer, Eric and Wester, Holger (1975): »Utrikes resor, arbetsvandringar och flyttningar i Finland och Vasa län 1861-90.» Österbotten 1975. Reports published by Svensk-Österbottniska Samfundet. Vasa 1975.

Finnäs, Fjalar (1973): Finlandssvenskarnas fruktsamhetsutveckling 1946-74. Åbo 1975.

Forsberg, Karl-Erik (1964): „Emigrations- och flyttningstenderser i svenska österbotten.» In Bidrag till kännedom av Finlands natur och folk. Published by Societas Scientiarum Fennica H 110. Helsingfors 1964.

Forsberg, Karl-Erik (1975): Finlandssvenskarna enligt folkräkningen 1970. Svenska befolkningsförbundets i Finland publikation $\mathrm{nr}$ 17. Helsingfors 1975.

Fougstedt, Gunnar (1951): „Finlands svenska befolkning åren 1936-1945. En demografisk undersökning.» In Bidrag till kännedom af Finlands natur och folk, published by Societas Scientiarum Fennica H 95, nr 2, Helsingfors 1951.

Häggström, Nils (1972): „Regionala och demografiska aspekter på flyttningsrörelserna mellan Finland och Sverige, åren 1968-70.» Rapport till Kulturfonden för Sverige och Finland, Geografiska Institutionen, Umeå Universitet, stencil.

Jungar, Sune (1974): Från Åbo till Ryssland. En studie i urban befolkningsrörlighet 1850-1890. Acta Academica Aboensis. Ser. A, Vol. 47, nr 3, Åbo 1974.

Klövekorn, Martin (1960): „Die sprachliche Struktur Finnlands 1880-1950. Veränderungen im sprachlichen Charakter der finnlandschwedischen Gebiete und deren bevölkerungs-, wirtschafts- und sozialgeographische Ursachen.» Bidrag till kännedom av Finlands natur och folk. Published by Societas Scientiarum Fennica, H, 105, Helsingfors 1960.

Majava, Altti (1975): "Migrations between Finland and Sweden from 1946 to 1974 . A Demographic Analysis.» Lic. thesis, stencil, Göteborg 1975.

Wester, Holger (1977): Innovationer i befolkningsrörligheten. En studie av spridningsförlopp i befolkningsrörligheten utgående från Petalax socken i Ósterbotten. Studia Historica Upsaliensia, 93, Uppsala 1977. 